\title{
Modulation of placental protein expression of OLR1: implication in pregnancy-related disorders or pathologies
}

\author{
M Ethier-Chiasson ${ }^{1,2}$, J-C Forest ${ }^{3}$, Y Giguère $^{3}$, A Masse ${ }^{4}$, C Marseille-Tremblay $^{1,2}$, E Lévy $^{5}$ \\ and J Lafond ${ }^{1,2}$ \\ ${ }^{1}$ Laboratoire de Physiologie Materno-Fœtale, Département des Sciences Biologiques, Université du Québec à \\ Montréal, Montréal, Québec, Canada H3C 3P8, ${ }^{2}$ Centre de Recherche BioMed, Université du Québec à Montréal, \\ Montréal, Québec, Canada H3C 3P8, ${ }^{3}$ Hôpital Saint-François d'Assise, Centre Hospitalier Universitaire de Québec, \\ Québec, Québec, Canada G1R 2J6, ${ }^{4}$ Hôpital St-Luc, Centre Hospitalier de I'Université de Montréal, Montréal, \\ Canada H2X $3 J 4$ and ${ }^{5}$ Hôpital Ste-Justine, Montréal, Québec, Canada H3T 1C5
}

Correspondence should be addressed to I Lafond at Laboratoire de Physiologie Materno-Fœtale, Centre de Recherche BioMed, Université du Québec à Montréal, C.P. 8888, Succursale Centre-Ville, Montréal, Canada H3C 3P8; Email: lafond.julie@uqam.ca

\begin{abstract}
The lectin-like oxidized low-density lipoprotein (LDL) receptor-1 (OLR1) is a newly described receptor for oxidatively modified LDL. The human pregnancy is associated with hyperlipidemia and oxidative stress. It has been reported that modification in maternal lipid profile can induce disturbance during pregnancy. In this study, we have evaluated the expression protein level of OLR1 in human term placenta of women having plasma cholesterol level lower to $7 \mathrm{mM}$ or higher to $8 \mathrm{mM}$ and women of gestational diabetes mellitus (GDM) by western blot analysis. The present study demonstrates that the maternal lipid profile is associated with placental protein expression of OLR1. A significant increase in the protein expression of OLR1 was observed in placenta of women with elevated plasmatic total cholesterol level $(>8 \mathrm{mM})$. In addition, the placental protein expression of OLR1 is increased in mothers having the highest prepregnancy body mass index $(\mathrm{BMI})$ and low $(<7 \mathrm{mM})$ plasmatic total cholesterol level at term. Interestingly, the placental protein expression of OLR1 is increased in the presence of GDM pregnancies compared with normal lipids level pregnancies, without the modification of mRNA expression. In conclusion, placental OLR1 protein expression is associated with maternal lipid profile, prepregnancy BMI, and pathology of GDM.

Reproduction (2008) 136 491-502
\end{abstract}

\section{Introduction}

The placenta is the central support organ for the developing fetus, serving as the site of maternal-fetal exchange of ions and lipids (Kanne et al. 2005). Human trophoblast differentiation is characterized by the formation of a specific multinuclear structure named the syncytiotrophoblast. The syncytiotrophoblast cells possess two structurally and functionally different plasma membranes: a brush border membrane (BBM) facing the maternal circulation and a basal plasma membrane (BPM) facing the fetal circulation (Lafond et al. 1988, Robidoux et al. 1998). During pregnancy, cholesterol is an essential component for placental and fetal development, used by the placenta for the synthesis of steroid hormones (Di Cianni et al. 2003). Physiological adaptations of maternal lipoprotein metabolism occur throughout pregnancy, leading to an increase in lipoprotein concentrations from second trimester to term. Maternal hypercholesterolemia is a characteristic feature during pregnancy and corresponds to an accumulation of triglycerides (TGs) in very-low-density lipoprotein (VLDL), low-density lipoprotein (LDL), and high-density lipoprotein (HDL; Warth et al. 1975, Herrera 2002). Although the exact mechanism of cholesterol transport across the placenta remains unclear, many studies suggest the implication of HDL as well as LDL, both providing cholesterol for placental hormone synthesis (Gwynne \& Mahaffee 1989). Early in pregnancy, maternal anabolic phase produces metabolic changes to support lipogenesis and fat storage in preparation for the catabolic phase of late pregnancy, a period of rapid fetal growth (Kaaja 1998). The maternal insulin resistance observed during this period increases lipolysis in adipose tissue, leading to an enhanced flux of fatty acids to the liver. This promotes the synthesis of VLDL resulting in an increase in TG concentrations. Moreover, insulin resistance reduces the activity of lipoprotein lipase, the enzyme responsible for VLDL clearance from plasma. Then, VLDL remains in the plasma for longer period and ultimately leads to the 
accumulation of LDL. Thus, this increase in LDL is directly associated with the development of atherosclerosis (Ross 1999).

Human placental cells express many lipoprotein receptors that can bind many lipoproteins such as the LDL receptor (LDLR; Cummings et al. 1982), the LDL receptor-related protein (LRP; Gafvels et al. 1992), the VLDL receptor (VLDL receptor; Wittmaack et al. 1995), the scavenger receptors (Bonet et al. 1995, Cao et al. 1997, Lafond et al. 1999), and the lectin-like oxidized LDL receptor-1 (OLR1; Yoshida et al. 1998). This latter one was recently cloned by Sawamura et al. (1997) and Moriwaki et al. (1998), and it can bind, internalize, and degrade the oxidized LDL (ox-LDL). OLR1 is a type II membrane glycoprotein belonging to C-type lectin family with a short $\mathrm{N}$-terminal cytoplasmic tail and a long C-terminal extracellular domain (Kita et al. 2001). It has a molecular weight of $47 \mathrm{kDa}$ and is initially synthesized as a $40 \mathrm{kDa}$ precursor protein (pre-OLR1), that has a minimal $\mathrm{N}$-linked high-mannose-type carbohydrate, which is further glycosylated into the mature protein and transported to the cell surface (Kataoka et al. 2000). OLR1 binds ox-LDL, delipidated, and solubilized ox-LDL, indicating that oxidatively modified apolipoprotein B-100 (apo-B) or some oxidized phospholipids firmly attached to the apoB might be ligands of OLR1 (Moriwaki, et al. 1998). In addition, this receptor is upregulated by pro-atherogenic conditions, such as dyslipidemia, hypertension, and diabetes (Nagase et al. 1997, Kume et al. 1998, Chen et al. 2000a, 2000b, 2001).

During human pregnancy, the maternal lipoprotein profiles are greatly modified (Herrera 2002). Fundamentally, pregnancy is associated with an oxidative stress state arising from the increasing metabolic activity of placental mitochondria and the decreasing scavenging by antioxidants (Wisdom et al. 1991). Products of lipid peroxidation have been detected in human placenta; LDLs are one of the main targets for lipid peroxidation and are converted to their oxidized form (Fialova et al. 2002). This process represents a key step in the development of atherosclerosis, since several studies showed that LDLs become atherogenic when they are converted to ox-LDL (Steinberg 1997, Witztum \& Horkko 1997). Because they have reduced affinity for the native LDLR, smaller and denser particles are considered to be more atherogenic. Thus, they are longer retained in the circulation, and become more inclined to oxidation, maybe because they contain less intrinsic antioxidants (Dejager et al. 1993, Rajman et al. 1999). ox-LDL becomes a ligand for scavenger receptors, including OLR1.

Affecting $3-7 \%$ of pregnant women, gestational diabetes mellitus (GDM) is characterized by endothelial dysfunction and reactive nitrogen and oxygen species, which contribute to the progression of diabetes (Honing et al. 1998, Rosen etal. 2001). In diabetes, reactive oxygen species (ROS), including superoxide, are thought to be produced as a result of prolonged periods of exposure to hyperglycemia, known to cause non-enzymatic glycation of plasma proteins (Tames et al. 1992). In addition, GDM is generally associated with disturbances in lipoprotein metabolism with a tendency toward hypercholesterolemia (Taskinen 1990). During pregnancy, women with GDM have higher serum TG concentrations, but lower HDL cholesterol concentrations than normal pregnant women (Koukkou et al. 1996).

We hypothesize that maternal lipid profile could modify placental expression of OLR1. Therefore, this study was designed to characterize the metabolic modifications of circulating lipids on the expression and localization of OLR1 in human term placenta of normal, hypercholesterolemic, and GDM pregnancies, and potentially correlate the modifications with BMI and some inflammatory cytokines. Thus, this study will provide better understanding of the regulation of important receptor involved in oxidized cholesterol metabolism and pregnancy-related disorders/pathologies, in which the lipid profile may be disturbed.

\section{Results}

\section{Subject characteristics}

Basic characteristics of mothers and newborns are given in Table 1. A total of 72 women gave birth and their blood samples were collected at term. The participants were split into two groups: low cholesterol (LC) women $(n=43)$ and high cholesterol (HC) women $(n=29)$. These groups were very similar according to the age of the women $( \pm 32$ years old), their gestational age at delivery ( \pm 39 weeks), and the mothers' BMI $\left( \pm 24 \mathrm{~kg} / \mathrm{m}^{2}\right)$. Also, no differences between groups were observed concerning the mothers' weight gain, the babies' weight and height at birth, and the placental weight.

\section{Plasma lipids at birth and in cord blood}

Table 2 shows total cholesterol, HDL cholesterol, LDL cholesterol, TG, apo-AI, and apo-B concentrations at delivery and in cord blood for LC and $\mathrm{HC}$ groups. Total cholesterol $(P<0.001)$, LDL cholesterol $(P<0.001)$, TG $(P=0.0029)$, and apo-B100 $(P<0.001)$ concentrations

Table 1 Population characteristics.

\begin{tabular}{lcc}
\hline & $\begin{array}{c}\text { LC group } \\
(<7 \mathrm{mM}) n=43\end{array}$ & $\begin{array}{c}\text { HC group } \\
(>8 \mathrm{mM}) n=29\end{array}$ \\
\hline Mother age (year) & $31.2 \pm 5.3$ & $31.2 \pm 4.2$ \\
Gestational age (week) & $39.0 \pm 1.5$ & $39.3 \pm 1.5$ \\
Mother BMI (kg/m $\left.{ }^{2}\right)$ & $23.5 \pm 5.0$ & $22.41 \pm 4.36$ \\
Mother weight gain $(\mathrm{kg})$ & $15.01 \pm 6.09$ & $18.83 \pm 6.81$ \\
Newborn birth weight $(\mathrm{g})$ & $3291 \pm 648$ & $3420 \pm 462$ \\
Newborn height $(\mathrm{cm})$ & $51.5 \pm 2$ & $52.0 \pm 5.0$ \\
Placenta weight $(\mathrm{g})$ & $592.4 \pm 154.1$ & $609.8 \pm 142.7$ \\
\hline
\end{tabular}

Results are expressed as mean \pm s.D. 
Table 2 Plasma lipids at delivery and in cord blood.

\begin{tabular}{|c|c|c|c|c|}
\hline & \multicolumn{2}{|c|}{ LC group $(<7 \mathrm{mM}) n=43$} & \multicolumn{2}{|c|}{ HC group $(>8 \mathrm{mM}) n=29$} \\
\hline & At delivery & Cord blood & At delivery & Cord blood \\
\hline Total cholesterol (mM) & $5.75 \pm 1.6$ & $1.88 \pm 0.94$ & $8.21 \pm 1.00^{+}$ & $1.68 \pm 0.51$ \\
\hline HDL cholesterol (mM) & $1.70 \pm 0.46$ & $0.75 \pm 0.31$ & $1.76 \pm 0.57$ & $0.73 \pm 0.31$ \\
\hline LDL cholesterol (mM) & $2.80 \pm 0.84$ & $0.84 \pm 0.54$ & $4.84 \pm 0.94^{\dagger}$ & $0.67 \pm 0.28$ \\
\hline TG (mM) & $2.71 \pm 1.12$ & $0.64 \pm 0.52$ & $3.59 \pm 1.21^{*}$ & $0.60 \pm 0.27$ \\
\hline Apo-Al (g/l) & $2.08 \pm 0.38$ & $0.90 \pm 0.36$ & $2.21 \pm 0.46$ & $0.83 \pm 0.23$ \\
\hline Apo-B100 (g/l) & $1.14 \pm 0.26$ & $0.30 \pm 0.23$ & $1.64 \pm 0.25^{\dagger}$ & $0.26 \pm 0.10$ \\
\hline
\end{tabular}

Results are expressed as mean \pm s.D., where $* P<0.01,{ }^{\dagger} P<0.001$ compared with the maternal LC group.

were significantly increased in $\mathrm{HC}$ women at delivery. The concentrations of $\mathrm{HDL}$ and apo-Al showed no differences between both groups. Also, no differences were observed in cord blood sample for both groups regarding all studied parameters.

\section{Protein expression of OLR1}

The expression of OLR1 was evaluated by western blot using total protein isolated from placental tissue. Figure $1 \mathrm{~A}$ shows a representative western blot of the expression of OLR1 and glyceraldehyde-3-phosphate dehydrogenase (GAPDH)

A
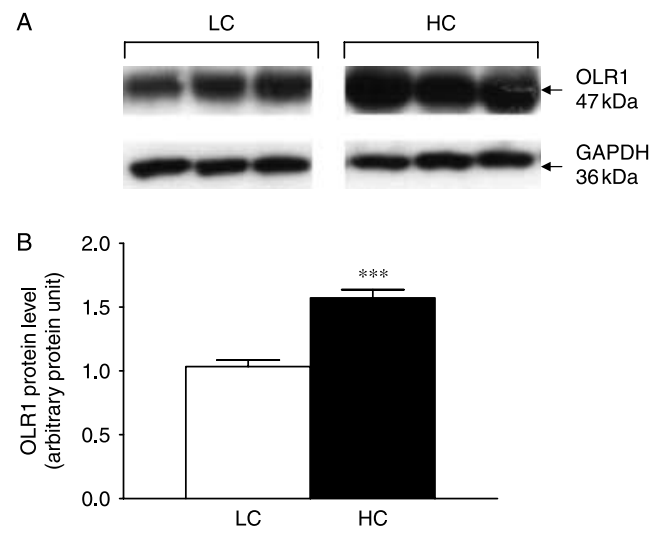

C

C Cytokines content in term placenta
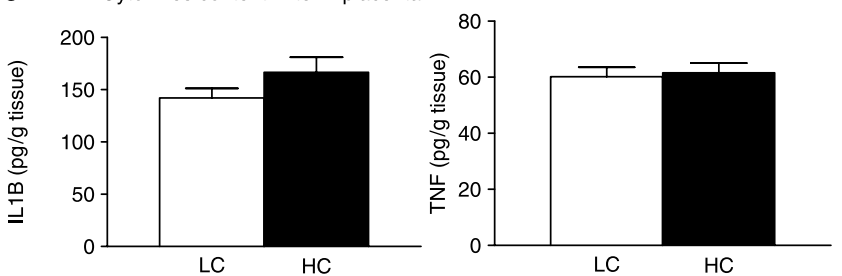

Figure 1 Representative protein expression of OLR1 and inflammatory cytokines concentration from total placental proteins extracts according to maternal plasmatic total cholesterol concentration. (A) Western blot analysis was performed using OLR1 antibody on total protein (150 $\mu \mathrm{g})$ isolated from placental tissue. Thereafter, the blot was stripped and reprobed with an anti-GAPDH antibody. (B) Densitometric analysis of OLR1 protein level after normalization with GAPDH protein level for LC $(n=43)$ and HC $(n=29)$ groups. (C) Inflammatory cytokines IL1B (right) and TNF (left) content in term placenta for LC $(n=31)$ and $\mathrm{HC}(n=21)$ groups. Results are expressed as mean \pm S.E.M., where ${ }^{* * *} P<0.001$. from placental tissue extracts. Following normalization with the GAPDH protein level, our results demonstrate that the expression of OLR1 is significantly increased $(68 \%)$ in HC group compared with LC one (Fig. 1B). Figure 2 shows the expression of OLR1 after its normalization with $\mathrm{GAPDH}$, in relation to different (A) pre-pregnancy $\operatorname{BMI}\left(<20 \mathrm{~kg} / \mathrm{m}^{2}, 20-26 \mathrm{~kg} / \mathrm{m}^{2}\right.$ and $\left.>26 \mathrm{~kg} / \mathrm{m}^{2}\right)$. For the LC groups (white bars), a significant increase in OLR1 protein expression in placenta of women with the highest BMI is observed compared with those with the lowest BMI $(P=0.0072)$, while for the HC women (black bars), no differences were observed between groups. In addition, our results show an increase in the protein expression of OLR1 between the $\mathrm{LC}$ and $\mathrm{HC}$ groups for the two lowest $\mathrm{BMI}$ groups ( $P=0.0002$ and $P<0.0001$, respectively).

\section{Level of inflammatory cytokines in term placenta}

To evaluate the role of inflammatory markers on OLR1 placental protein expression, the quantification of interleukin $1 \beta$ (IL1B) and tumor necrosis factor- $\alpha$ (TNF) was done. These cytokines are highly expressed in placenta, principally IL1B. Figure 1C shows the IL1B and TNF concentrations in human term placenta in relation to maternal plasmatic total cholesterol level at term. Our results demonstrate that these cytokines were not influenced by maternal plasmatic total cholesterol level, were neither influenced nor by maternal pre-pregnancy BMI (Fig. 2B). Finally, in HC women, placental IL1B level was influenced by weight gain during pregnancy (data not shown). Specifically, an increase of $\pm 65 \%$ is observed between women who gained $>18 \mathrm{~kg}$ compared with women with normal weight gain $(11-18 \mathrm{~kg} ; 235.2 \pm 38.03$ vs $139.2 \pm 11.54$ respectively). No difference was showed for TNF related to weigh gain (data not shown).

\section{Protein expression of OLR1 in syncytiotrophoblast membranes}

The expression of OLR1 was evaluated by western blot in syncytiotrophoblast plasma membranes (BPM and $\mathrm{BBM}$ ), isolated form fresh placenta. Figure 3 shows representative western blot of the expression of OLR1 in BPM, BBM, syncytiotrophoblast cells, and total protein from placental tissue. Expression of OLR1 protein, which 
A
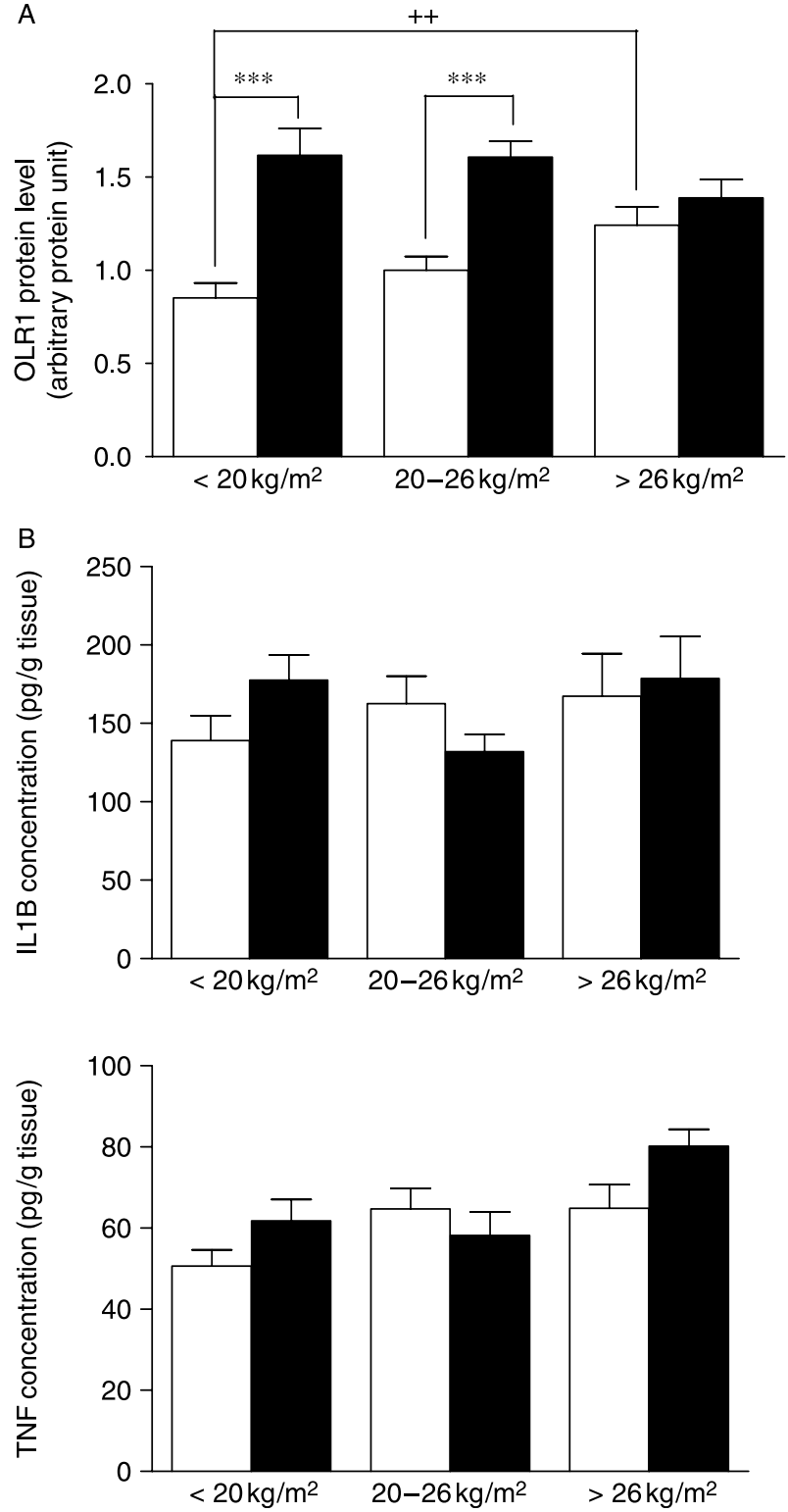

Figure 2 Representative protein expression of OLR1 and inflammatory cytokines concentration from total placental proteins extracts according to maternal pre-pregnancy BMI. (A) Densitometric analysis of OLR1 protein level after normalization with GAPDH protein level. Western blot analysis was performed using OLR1 or GAPDH antibody in total proteins $(150 \mu \mathrm{g})$ extracted from placental tissue. (B) Inflammatory cytokines IL1B (top) and TNF (bottom) contents in term placenta. Results are expressed as mean \pm s.E.M., where ${ }^{++} P<0.01$ and ${ }^{* * *} P<0.001$.

has a molecular weight of $47 \mathrm{kDa}$, was detected in both placental membranes, in syncytiotrophoblastic cells and in total protein extract from placenta.

\section{Immunohistochemical study of OLR1}

As shown in Fig. 4, immunohistochemical study of OLR1 expression in human placenta demonstrated that it was localized in both maternal BBM and fetal BPM sides of

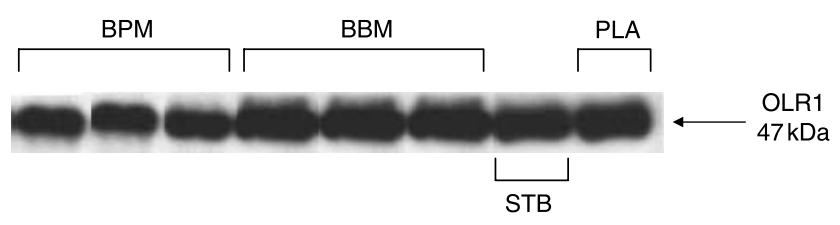

Figure 3 Representative protein expression of OLR1 in human placental tissues. Proteins $(150 \mu \mathrm{g})$ were migrated on an $8 \%$ SDS-PAGE under reducing conditions. Blots were done with OLR1 antibody. Maternal side purified membranes (BBM), fetal side purified membranes (BPM), syncytiotrophoblast (STB; $n=3)$, and total protein extract from placental tissue (PLA; $n=3$ ).

syncytiotrophoblast cells and in fetal capillaries (Fig. 4A). OLR1 stained strongly immunopositive principally in BBM.

\section{Correlations between OLR1 protein expression and circulating plasma lipids}

The correlation between OLR1 protein expression and many maternal plasma circulating lipids was evaluated by Spearman's correlation and Pearson's linear correlation curves. Positive correlations were observed between OLR1 protein expression and maternal plasmatic total cholesterol level $(r=0.4248, P=0.001)$, LDL plasma level $(r=0.4102, P=0.0019)$, and apo-B100 level $(r=0.3885$, $P=0.0018$ ) at term, as shown in Fig. 5A, B and D (left plots) respectively. By contrast, no correlation was marked between the OLR1 protein expression and maternal plasma HDL level $(r=0.1292, P=0.4619)$ at term (Fig. 5C). In addition, no correlation was found between OLR1 protein expression and cord blood total plasma cholesterol $(r=-0.0773, P=0.5725)$, LDL cholesterol $(r=-0.1680, P=0.3737), \mathrm{HDL}$ cholesterol $(r=-0.03027, P=0.7236)$ and apo-B100 $(r=0.07784$, $P=0.8223$ ) levels (Fig. 5A-D, right plots).

\section{Population characteristics for women with GDM}

Basic characteristics for mothers and newborns are given in Table 3. A total of 24 women gave birth and their blood samples were collected at term. The participants were split into two groups: control women $(n=15)$ and GDM women $(n=9)$. The age of the women was \pm 31 years old, and their gestational age was about 39 weeks. Compared with controls women, the GDM women had significant highest BMI (23.2 \pm 0.7 vs $27.8 \pm 1.9 ; P=0.0242)$. No differences were observed according to the maternal weight gain, weight and height at birth for babies of both groups, and placental weight.

\section{Plasma lipids during pregnancy and at birth of GDM women}

Table 4 presents total cholesterol, HDL cholesterol, LDL cholesterol, TG, apo-AI, and apo-B100 concentrations at 

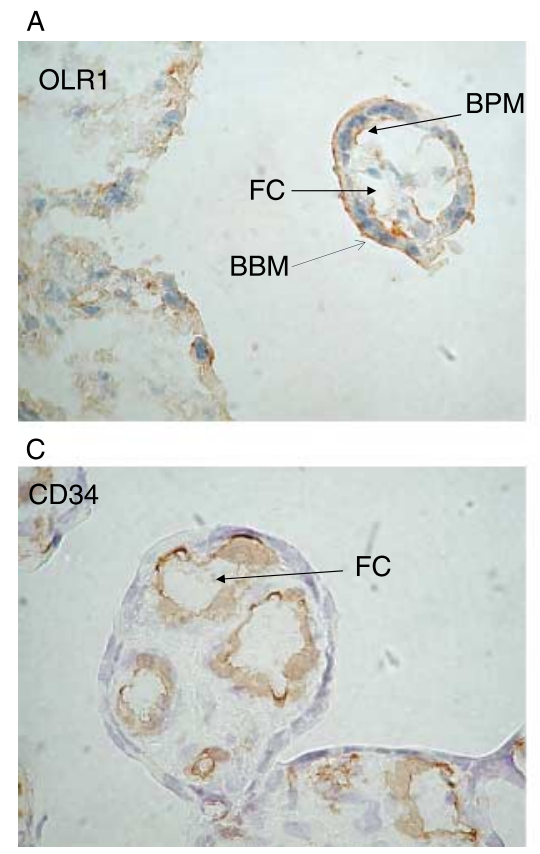

B

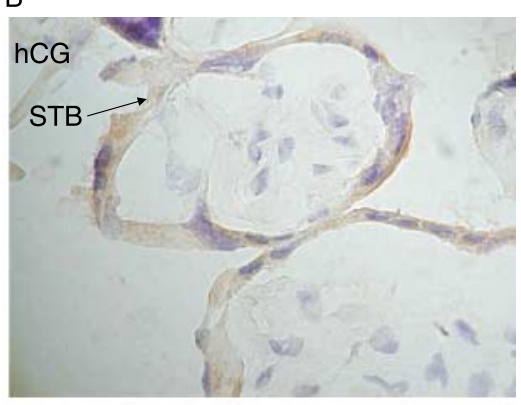

D

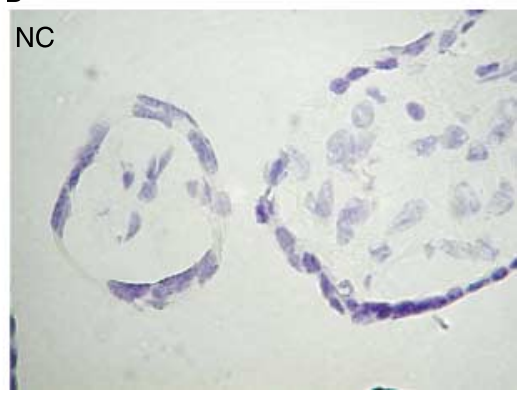

Figure 4 Immunohistochemical expression of OLR1 in human placental tissue. Shortly, frozen placental tissues were cut and fixed on glass slides. After being incubated with primary antibodies, slides were stained and viewed under interference contrast microscope. Positive staining is in brown color and nuclear counterstaining is blue. (A) OLR1 is present in both maternal (BBM) and fetal (BPM) sides of syncytiotrophoblast (STB) from term placenta as well as in fetal capillary (FC). (B) The positive control (hCG) is present in syncytiotrophoblast while $(\mathrm{C})$ the endothelial marker, CD34, is present on fetal capillaries (FC). (D) Negative control (NC) consists of placental tissue without primary antibody. delivery and in cord blood for control and GDM women. No differences were observed for total cholesterol, LDL cholesterol, HDL cholesterol, apo-AI, and apo-B100 at delivery. However, GMD subjects had significantly higher concentration of TG at delivery compared with control women (2.26 vs 3.17; $P=0.0077)$. Also, no differences were observed in cord blood samples for total cholesterol, HDL cholesterol, TG, apo-Al, and apo-B100, while GDM condition induced a significant decrease in total cholesterol (1.99 vs $1.65 ; P=0.0407)$ and LDL cholesterol (1.03 vs 0.68 ; $P=0.0068)$ in cord blood.

\section{mRNA expression of OLR1 in GDM condition}

The expression of OLR1 was evaluated by real-time PCR using mRNA isolated from placental tissue. Figure 6 presents the relative quantification, using $18 \mathrm{~S}$ as reference gene. We observed no difference in GDM women compared with control ones (0.6422 vs 0.6591$)$.

\section{Protein expression of OLR1 in GDM women}

The expression of OLR1 was evaluated by western blot using total protein isolated from placental tissue. Figure 7A shows representative western blot of the expression of OLR1 and GAPDH from placental tissue ( $n=3$ for each group). Following normalization with GAPDH protein level, our results (Fig. 7B) show that the expression of OLR1 in GDM women is significantly increased by $53 \%$ compared with the control ones (0.5354 vs $1.006 ; P=0.0015)$.

\section{Inflammatory cytokines level in term placenta of women with GDM}

Figure $7 \mathrm{C}$ shows the concentration of IL1B and TNF in term placenta of GDM and CTL women. Our results clearly demonstrated that these cytokines were modified in GDM group since both placental IL1B and TNF were significantly increased (0.0139 and 0.0437 respectively).

\section{Discussion}

Our study shows that maternal lipid profile is associated with OLR1 protein expression in human term placenta. Specifically, placental OLR1 protein expression is increased in case of maternal hypercholesterolemia and GDM, and is affected by pre-pregnancy BMI. In addition, in the present study, we show for the first time the expression of OLR1 in both maternal BBM and fetal sides BPM of normal human placenta.

Abnormally high plasma lipid concentration is thought to be an important pathogenic factor, principally in atherogenesis. It is known that OLR1 expression is increased in case of hypertension, atherosclerosis, and hyperlipidemia in vivo (Mehta et al. 2006). A study using apo-E knockout mice, a model for spontaneous hypercholesterolemia, the OLR1 expression is reduced by feeding mice with a HMG-CoA reductase inhibitor (Chen et al. 2006), which decreases LDL cholesterol level and reduces the formation and uptake of ox-LDL (Chen et al. 2000a, 2000b). Our data are in accordance with these observations since we showed a positive correlation between plasma total cholesterol, LDL cholesterol, and apo-B100 levels with placental protein 

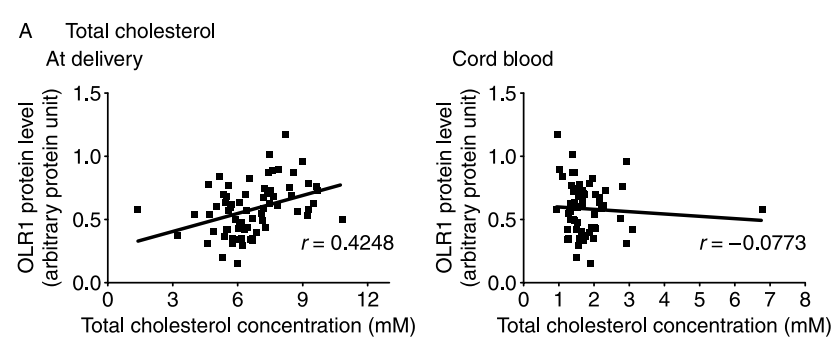

B LDL cholesterol

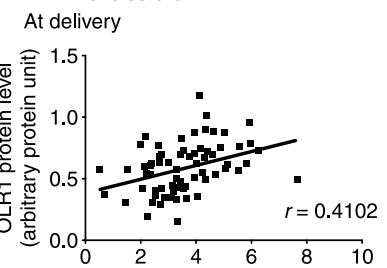

$\mathrm{LDL}$ cholesterol concentration (mM)

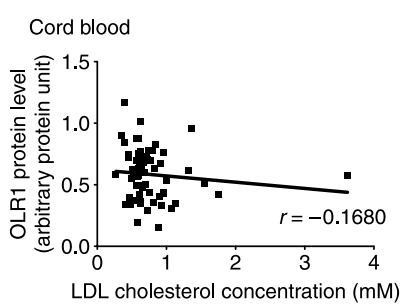

C HDL cholesterol

At delivery
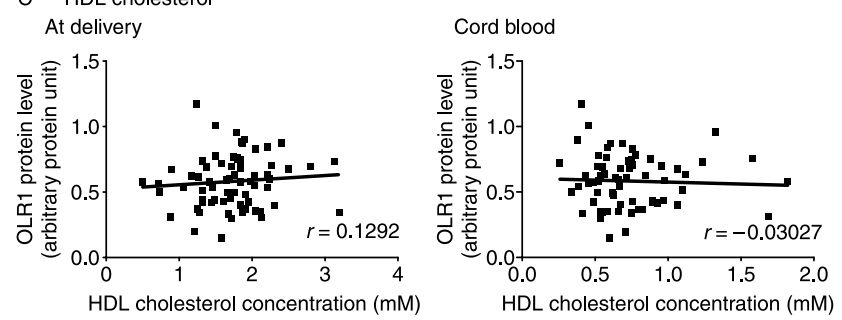

D Apo-B100

At delivery
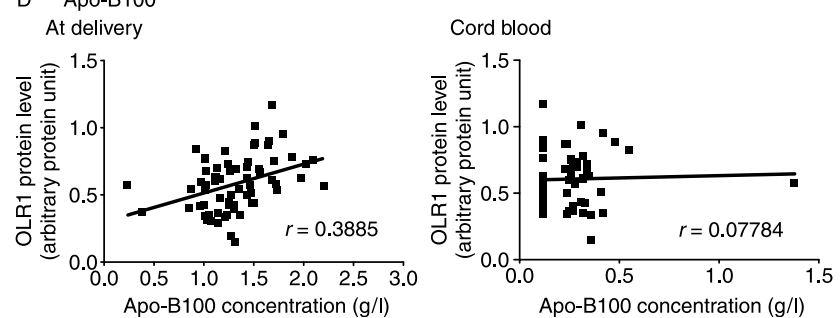

Figure 5 Relationship between OLR1 protein expression and maternal plasmatic lipids concentration at delivery and in cord blood. (A) Total cholesterol $(n=83),(\mathrm{B})$ LDL cholesterol $(n=68)$, (C) HDL cholesterol $(n=70)$, and (D) apo-B100 $(n=79)$. Results are expressed as Spearman's correlation and the curve represent Pearson's linear correlation.

expression of OLR1. In contrast to non-pregnant women, there is a physiological change in plasma lipids and an increased oxidative turnover that is controlled by countervailing anti-oxidative mechanisms in healthy pregnant women (Toescu et al. 2002). In response to the high demand by the fetus, there is an increase production of ROS by the placenta during pregnancy. On the other hand, placenta is a source of an anti-oxidative enzyme and hormone system that controls placental lipid peroxidation in healthy pregnancy (Gitto et al. 2002). Many studies reported higher levels of placental lipid peroxides in pre-eclampsia than in normal pregnancies (Walsh \& Wang 1993, Gratacos et al. 1998, Serdar et al. 2002), suggesting that placental tissues could be the source of elevated levels of serum
Table 3 Population characteristics of women with gestational diabetes mellitus.

\begin{tabular}{lcc}
\hline & $\begin{array}{c}\text { Control group } \\
(n=15)\end{array}$ & $\begin{array}{c}\text { GDM group } \\
(n=9)\end{array}$ \\
\hline Mother age (year) & $32.5 \pm 3.6$ & $30.9 \pm 1.6$ \\
Gestational age (week) & $40.1 \pm 0.4$ & $39.2 \pm 0.2$ \\
Mother BMl (kg/m $\left.{ }^{2}\right)$ & $23.2 \pm 0.7$ & $27.8 \pm 1.9^{*}$ \\
Mother weight gain $(\mathrm{kg})$ & $13.5 \pm 1.0$ & $11.8 \pm 1.6$ \\
Newborn birth weight $(\mathrm{g})$ & $3591 \pm 121.5$ & $3607 \pm 99.8$ \\
Newborn height $(\mathrm{cm})$ & $52.0 \pm 0.6$ & $51.8 \pm 0.5$ \\
Placenta weight $(\mathrm{g})$ & $554.5 \pm 34.7$ & $598.1 \pm 71.7$ \\
\hline
\end{tabular}

Results are expressed as mean \pm s.D. where $* P<0.05$ compared with control group.

lipid peroxides. Finally, it has been reported that OLR1 was the principal scavenger receptor responsible for the uptake of ox-LDL in placental cells (Pavan et al. 2004). Thus, the high level of OLR1 placental protein expression can be explained by the enhancement of oxidative stress in $\mathrm{HC}$ women. Obviously, the importance of oxidative stress in pregnant women and the lack of knowledge in this population justify pursuing studies in this particular field.

In this study, we demonstrated that pre-pregnancy BMI significantly increased placental OLR1 protein expression in LC women. We first hypothesized that this increase could be attributed to the inflammatory status observed in obesity (Chen 2006). It is well known that adipose tissue is a highly active endocrine organ secreting a number of hormones that alter the circulation of metabolites, cytokines, and growth factors (Grundy 2004, Havel 2004). Thus, obese women are more likely than normal weight women to enter pregnancy in a subclinical inflammatory state since increases in body fat are associated with elevated cytokine levels and inflammation (Greenberg \& Obin 2006). Surprisingly, our data showed no difference for both IL1B and TNF in relation to maternal BMI. However, this effect could be attributed to the fact that maternal adiposity could also produced a hypoxic state when glycosylated hemoglobin levels are increased and affinity for oxygen is reduced, decreasing oxygen transfer to the uterus and impairing placentation (King 2006). Thus, many molecules related to oxidative stress can induce the expression of OLR1, such as isoprostanes, which are prostaglandin isomers formed by free radical peroxidation of arachidonic acid presents in phospholipids (Sakurai \& Sawamura 2003). Among these isoprostanes, 8-iso-prostaglandin $F_{2} \alpha$, a well-known marker of oxidative stress (Sakurai \& Sawamura 2003), has the potential to increase the uptake of oxidized LDL and the expression of OLR1 in human placenta choriocarcinoma JAR cells (Halvorsen et al. 2001). Some of our data showed that maternal weight gain had no effect on placental OLR1 protein expression. In contrast, our results demonstrated an increase in IL1B content for HC women with normal weight gain (11-18 kg) compared 
Table 4 Plasma lipids during pregnancy and in cord blood of women with gestational diabetes mellitus.

\begin{tabular}{|c|c|c|c|c|}
\hline & \multicolumn{2}{|c|}{ Control group $(n=15)$} & \multicolumn{2}{|c|}{ GDM group $(n=9)$} \\
\hline & At delivery & Cord blood & At delivery & Cord blood \\
\hline Total cholesterol $(\mathrm{mM}))$ & $6.41 \pm 0.23$ & $1.99 \pm 0.1$ & $6.22 \pm 0.32$ & $1.65 \pm 0.10^{*}$ \\
\hline HDL cholesterol (mM) & $1.85 \pm 0.11$ & $0.72 \pm 0.06$ & $1.62 \pm 0.11$ & $0.69 \pm 0.04$ \\
\hline LDL cholesterol (mM) & $3.52 \pm 0.19$ & $1.03 \pm 0.08$ & $3.15 \pm 0.20$ & $0.68 \pm 0.06^{\dagger}$ \\
\hline $\mathrm{TG}(\mathrm{mM})$ & $2.26 \pm 0.14$ & $0.51 \pm 0.04$ & $3.17 \pm 0.32^{+}$ & $0.61 \pm 0.12$ \\
\hline Apo-Al (g/l) & $2.09 \pm 0.08$ & $0.89 \pm 0.04$ & $2.10 \pm 0.09$ & $0.82 \pm 0.05$ \\
\hline Apo-B100 (g/l) & $1.23 \pm 0.04$ & $0.29 \pm 0.04$ & $1.26 \pm 0.07$ & $0.22 \pm 0.03$ \\
\hline
\end{tabular}

Results are expressed as mean \pm S.D., where $* P<0.05,{ }^{+} P<0.01$, compared with control group.

with $\mathrm{HC}$ women with lowest weight gain $(<11 \mathrm{~kg})$. The precise relationship between this cytokines and maternal weight gain remains unclear and further investigations will be necessary.

The present study demonstrates the localization of OLR1 in both maternal BBM and fetal BPM sides of syncytiotrophoblasts. The binding of ox-LDL with OLR1 induces superoxide generation, inhibits NO production, enhances endothelial adhesiveness for leucocytes, and induces chemokine expression (Cominacini et al. 2000, Li \& Mehta 2000). Thus, the presence of OLR1 in both sides of syncytiotrophoblasts may promote apoptosis (Lee et al. 2005). A recent study shows that the functional role of trophoblasts in placental dysfunction results from the localization and the upregulation of OLR1 in preeclamptic placenta, which possibly promotes apoptotic activity (Lee et al. 2005). Since OLR1 is a receptor for ox-LDL, a highly atherogenic lipoprotein, physiological functions of placental cells may be altered. Thus, maternal hypercholesterolemia could promote fetal atherosclerosis development via OLR1. Finally, further investigations will be required to understand the precise role of these two binding sites.

GDM induces a state of dyslipidemia consistent with insulin resistance. Indeed, during pregnancy, GDM women had higher plasma TG concentrations (Butte 2000). In normal pregnancy, the higher concentration of estrogens and insulin resistance are considered to be responsible for the hypertriglyceridemia (Butte 2000),

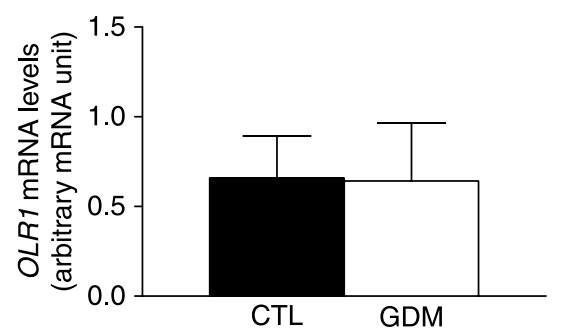

Figure 6 Quantification of OLR1 mRNA level in human term placenta. Quantification was performed by real-time PCR for CTL $(n=15)$ and $\operatorname{GDM}(n=9)$. Briefly, total RNA was extracted from placental tissue and RT was performed in a $20 \mu \mathrm{l}$ reaction containing $0.5 \mu \mathrm{g}$ total RNA and the Oligo-dT primers. The PCRs were performed using $0.5 \mu \mathrm{M}$ of both sense and antisense primers, for 55 cycles. Results are expressed as mean \pm s.E.M. while in GDM women, increased insulin resistance may account to the rise in TG concentration (Koukkou et al. 1996). In this study, we found an increase in TG concentration at delivery and a decrease in total and LDL cholesterol in cord blood of GDM women. A novel study shows that GDM increased the LDL susceptibility to oxidation, a susceptibility due to diabetes per se, as well as the increase in incidence of obesity found in these women (Sanchez-Vera et al. 2007). This fact is in accordance with our results, since we found that GDM women had higher BMI than control ones. It is known that hyperlipidemia is exaggerated in obese pregnant women (Ramsay et al. 2002). This fact could be attributed to the inability of insulin to suppress wholebody lipolysis, leading to a marked increase in plasma

A

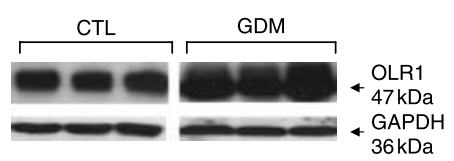

B

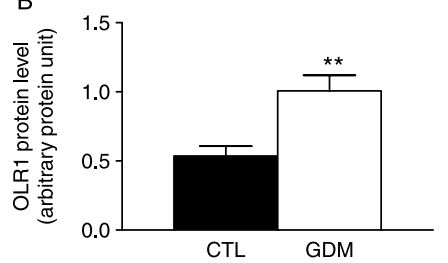

C
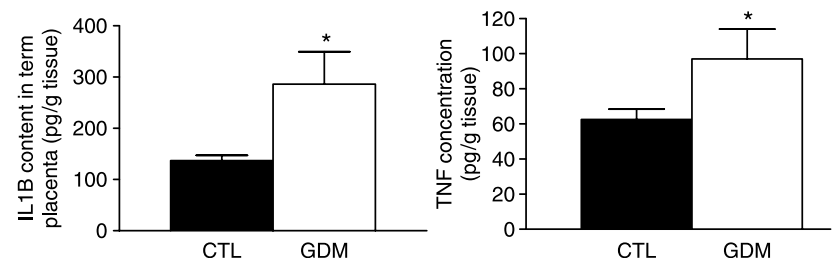

Figure 7 Representative protein expression of OLR1 and inflammatory cytokines content extracts from human term placenta. (A) Western blot analysis of OLR1 on total protein $(150 \mu \mathrm{g})$ isolated from placental tissue. Thereafter, the blot was stripped and reprobed with an anti-GAPDH antibody. (B) Densitometric analysis of OLR1 protein level in CTL $(n=10)$ and GDM $(n=6)$ women after normalization with GAPDH protein level. (C) Inflammatory cytokines, IL1B (right) and TNF (left), content in term placenta of CTL $(n=10)$ and GDM $(n=6)$ women. Results expressed as mean \pm S.E.M., where ${ }^{* *} P<0.01$ and ${ }^{*} P<0.05$. 
free fatty acids in obese women compared with control women (Xiang et al. 1999). The decrease in total cholesterol and LDL cholesterol concentrations, found in cord blood of babies from GDM women, may be attributed to a decrease in the placental blood flow and placental damage due to lipid peroxides generated by the increased LDL oxidation. As a result, this would compromise the supply of nutriment toward the fetus. An important finding of our study is that GDM increases placental OLR1 protein expression without affecting mRNA expression levels. This result, for the protein expression, is in accordance with other studies that demonstrated the increase in OLR1 expression in different tissues of diabetic subjects. It has been reported that OLR1 expression is increased by glucose both in macrophage and endothelial cells (Li et al. 2003, 2004). Effectively, diabetes is characterized by the presence of an important oxidative stress, endothelial dysfunction, and increased expression of endothelial molecules in the inflammatory cells (Stevens 2005). Thus, this effect could be attributed to the maternal inflammatory status; in a recent study, an increase in cytokines concentration in maternal blood with GDM was observed (Heitritter et al. 2005). This finding agrees with our results where we demonstrated a significant increase in two central mediators of inflammatory reaction, IL1B and TNF, in placenta of women with GDM. Finally, we show that this increase is more pronounced for placental IL1B, while this cytokine is associated with the risk of developing type 2 diabetes (Spranger et al. 2003). In fact, several studies show that proinflammatory cytokines regulate the expression of OLR1 (Kume et al. 2000, Chiba et al. 2001, Hofnagel et al. 2006). A study using smooth muscle cells showed that strong co-distribution of proinflammatory cytokines, IL1A and IL1B, and TNF with OLR1 expression promotes atherosclerosis lesions (Hofnagel et al. 2006). Moreover, pregnancy induces inflammatory changes characterized by the activation of peripheral blood leucocytes (Sacks et al. 1998), and the production of pro-anti-inflammatory cytokines such as IL6 and TNF. Finally, this increase in OLR1 expression observed in women with GDM could be regulated by a post-transcriptional mechanism implying these cytokines. Finally, babies delivered under GDM were normal, resulting in the maternal intake of insulin during the third trimester of pregnancy (Challier et al. 1986). To conclude, all of these facts are in accordance with our data, where we found that placental protein expression of OLR1 is increased in women with GDM.

In summary, our results corroborate the importance of the maternal lipid profile during pregnancy. Thus, maternal hypercholesterolemia, as well as GDM, could promote fetal atherosclerosis development via an upregulation of placental expression of OLR1. In addition, we reported for the first time the presence of OLR1 in both maternal and fetal sides of syncytiotrophoblasts. Taking together, these data suggest that the post-transcriptional modulation of placental protein expression OLR1 by maternal lipid profile disturbance or pathologies during pregnancy can ultimately influence fetal growth and development.

\section{Materials and Methods Study population}

The women participating in the study were recruited at their first prenatal visit, before their tenth week of pregnancy, at the Clinique Fidès of Montreal and at the Service of Perinatalogy, of the Centre Hospitalier de I'Université de Montréal (CHUM), Pavilion St-Luc, QC, Canada, from 2002 to 2006. After signing a consent form, each woman filled out an interviewadministrated questionnaire, which contained general sociodemographic data, medical history, drinking, and smoking habit. The total study population consisted of 900 pregnant women. To conduct this study, 81 women were selected. Of these women, 72 had a normal pregnancy, while 9 developed GDM. The ones from normal pregnancy were classified into two groups according to the plasmatic total cholesterol concentration at term. To establish the groups, we established the median of maternal plasmatic total cholesterol at term (6.42 mM). Women with lower than $7 \mathrm{mM}$ referred to the LC group $(n=43)$ and women with cholesterol concentration higher than $8 \mathrm{mM}$ referred to the HC group. Subsequently, they were reclassified into three groups according to their prepregnancy body mass index (BMI). The BMI, representing a measure of adiposity, was calculated as pre-pregnancy $\mathrm{kg} / \mathrm{m}^{2}$. The established normal values for BMI, according to the Health Canada (2002), were between 20 and $26 \mathrm{~kg} / \mathrm{m}^{2}$. Women who developed GDM $(n=9)$ were matched with 15 control (CTL) women giving birth between 37 and 40 weeks of pregnancy, having normal lipid profile, normal values for BMI, and weight gain. Screening for diabetes pregnancy was done according to the CHUQ and CHUM protocols (Forest et al. 1983, 1994). Pregnant women were screened for GDM between 24 and 32 weeks with the $50 \mathrm{~g}$ glucose challenge test. The subject having a serum glucose values equal or greater than $7.8 \mathrm{mmol} / \mathrm{l}$, women were tested with the $100 \mathrm{~g}$ oral glucose tolerance test. All of these women were non-smokers and did not receive any medication known to interfere with lipid metabolism. Finally, a post-natal follow-up was made to assess newborns' health status as well as collecting data relative to the weight and height of the babies.

\section{Blood samples}

Blood samples were collected at delivery, from the mother and the cord blood. The blood samples were collected in $10 \mathrm{ml}$ gel Vacutainer tube gel (BD, Oakville, Canada) and centrifuged for $15 \mathrm{~min}$ at $3500 \mathrm{~g}$, less than $1 \mathrm{~h}$ after delivery. Plasma samples were kept at $-20{ }^{\circ} \mathrm{C}$ until analysis. The placentas, from vaginal delivery, were obtained from the collaborating hospital and immediately immersed in Dulbecco's modified Eagle's medium (Sigma) containing a mixture of antibiotic (penicillin, streptomycin, and neomycin; Invitrogen) and $\mathrm{NaHCO}_{3}$. After the removal of the amnion, chorion and decidual layers, the 
placental tissue was cut into sections of $5 \mathrm{~cm}^{2}$ and immediately frozen in liquid nitrogen and kept at $-80^{\circ} \mathrm{C}$ until use.

\section{Lipid assays}

The plasma levels of total cholesterol and LDL, HDL, VLDL, and TG were individually measured using the Unicel 36 DX600 Synchron Clinical System (Beckman-Coulter, Mississauga, ON, Canada), at the Clinical Biochemistry Service of Hôpital Saint-François d'Assise, Québec (QC, Canada).

\section{Total proteins extraction}

The placental frozen tissue samples were washed three to four times with $0.9 \%$ cold $\mathrm{NaCl}$ solution containing anti-protease (1 $\mu \mathrm{M}$ leupeptin, $1.46 \mu \mathrm{M}$ pepstatin, and $2 \mu \mathrm{g} / \mathrm{ml}$ aprotinin) to remove blood from tissue. The tissue $(1 \mathrm{~g})$ was homogenized using a Polytron tissue homogeniser PT 3000 (Brinkmann, Canada) in $1 \mathrm{ml}$ ice-cold hypertonic buffer $(125 \mathrm{mM}$ Tris- $\mathrm{HCl}$, $\mathrm{pH}$ 8.0, $2 \mathrm{mM} \mathrm{CaCl}_{2}, 1.4 \%$ (v/v) Triton X-100, $1 \mu \mathrm{M}$ leupeptin, $1.46 \mu \mathrm{M}$ pepstatin, $2 \mu \mathrm{g} / \mathrm{ml}$ aprotinin, and $1 \mathrm{mM}$ phenylmethylsulphonylfluoride (PMSF)). The homogenate was kept on ice for $30 \mathrm{~min}$, centrifuged at $10000 \mathrm{~g}$ for $25 \mathrm{~min}$ at $4{ }^{\circ} \mathrm{C}$, the supernatant was collected, and stored at $-80^{\circ} \mathrm{C}$ until used. The protein concentration content was determined by spectrophotometric quantification using the bicinchoninic acid reagent (Pierce, Brockville, ON, Canada) with BSA as standard.

\section{Purification of syncytiotrophoblast BBM and BPM}

Briefly, membranes were purified from placental tissues collected from fresh human placentas obtained from full-term normal vaginal delivery (CHUM, Pavilion St-Luc, QC, Canada). After the removal of the amnion, chorion and decidual layers, the tissues were minced and stirred for $45 \mathrm{~min}$ in $10 \mathrm{mM}$ TrisHEPES ( $\mathrm{pH}$ 7.4) containing $270 \mathrm{mM}$ mannitol, $0.1 \mathrm{mM}$ PMSF, $1 \mathrm{mg} / \mathrm{ml}$ benzamidin, and $10 \mathrm{mM}$ leupeptin. The membranes were purified, as described by our laboratory (Lafond et al. 1988) with some modifications (Robidoux et al. 1998).

\section{Western blot analyses of OLR1}

Total placental proteins $(150 \mu \mathrm{g}$ for total placental protein and $30 \mu \mathrm{g}$ for syncytiotrophoblastic membranes) were solubilized $\mathrm{n}$ a sample buffer (4\% SDS, $30 \mathrm{mM}$ dithiotreitol, 10\% $\beta$-mercaptoethanol, $0.25 \mathrm{M}$ sucrose, $0.01 \mathrm{M}$ EDTA- $\mathrm{Na}_{2}$, and $0.075 \%$ bromophenol blue) and heated at $95{ }^{\circ} \mathrm{C}$ for $5 \mathrm{~min}$. The proteins were resolved in a $8 \%$ SDS-PAGE and electroblotted to PDVF membrane (Millipore, Cambridge, ON, Canada) at $20 \mathrm{~V}$ for $40 \mathrm{~min}$. Membranes were blocked overnight at $4{ }^{\circ} \mathrm{C}$ in TBS-T (20 mM Tris base, pH 7.6, $137 \mathrm{mM} \mathrm{NaCl}$, and 0.1\% Tween-20) containing 5\% skimmed milk. Thereafter, the membranes were washed three times with TBS-T and incubated with anti-human OLR1 goat polyclonal antibody (Santa Cruz Biotechnology, Santa Cruz, CA, USA; 1/1000 in TBS-T/5\% BSA and 1\% skimmed milk), or human GAPDH mouse MAB (Chemicon International, Temecula, CA, USA; $1 / 5000$ in TBS-T/5\% BSA) for $90 \mathrm{~min}$ at room temperature. Blots were washed three times with TBS-T, and probed with horseradish peroxidase-conjugated secondary antibodies, for OLR1, anti-goat IgG (1/6500 TBS-T 5\% BSA and $1 \%$ skimmed milk) and for GAPDH anti-mouse IgG (1/3000 TBST 5\% skimmed milk; Chemicon International) for $90 \mathrm{~min}$ at room temperature. Blots were then washed three times with TBS-T and the detection was performed using the BM chemiluminescence system (Roche Diagnostics) and visualized by autoradiography (Hyperfilm ECL, GE Healthcare, Baie d'Urfée, QC, Canada). The PDVF membranes were stripped with a stripping solution (12 M $\mathrm{HCl}(\mathrm{pH} 2.0) 25 \mathrm{mM}$ glycine, and 1\% SDS) for $10 \mathrm{~min}$ at room temperature. Thereafter, the membranes were rinsed three times with a washing solution ( $1 \mathrm{MNa}_{2} \mathrm{HPO}_{4}, 1 \mathrm{MNaH}_{2} \mathrm{PO}_{4}$ (pH 7.2), and $9 \mathrm{~g} / \mathrm{l} \mathrm{NaCl}$ ) for $5 \mathrm{~min}$ and blocked for $1 \mathrm{~h}$. The membranes were then ready to be reprobed with GAPDH for loading standardization. We normalized data with a control sample that served to express data as percentage of control. For semiquantitative analyses of the bands, the film was digitized and analyzed by the Quantity One Software (Bio-Rad Laboratories).

\section{RNA analysis}

Total RNA was extracted from placental tissue using the High Pure RNA Tissue Kit (Roche Diagnostics). The RT was performed in a $20 \mu \mathrm{l}$ reaction containing $0.5 \mu \mathrm{g}$ total RNA using the Omniscript kit (Qiagen) and the Oligo-dT primers (Roche Diagnostics) according to the manufacturer's instructions. The real-time PCRs were realized using the 480 SYBR Green I Master (Roche Diagnostics) on a LightCycler 480 Instrument (Roche Diagnostics). The PCRs were performed using $0.5 \mu \mathrm{M}$ of both sense and antisense primers, for 55 cycles to ensure exponential amplification phase of the targeted genes. Primer sequences designed for human OLR1 were: $\left(5^{\prime}-3^{\prime}\right)$ (sense) TTACTCTCCATGGTGGTGGTGCC and (antisense) AGCTTTCTTCTGCTTGTTGCC. Human $18 \mathrm{~S}$ primers, as reference gene, were: $\left(5^{\prime}-3^{\prime}\right)$ (sense) AGAGCTAATACATGCCGAC and (antisense) AGTTGATAGGGCAGACG.

\section{Immunohistochemistry}

An immunohistochemistry study was performed to investigate the localization of OLR1 protein. We used appropriate placental tissues from fresh placentas. After the removal of the amnion, chorion and decidual layers, the placental tissue was cut into sections of $5 \times 5 \times 5 \mathrm{~mm}$, embedded in cold $\left(4{ }^{\circ} \mathrm{C}\right)$ Tissue-tek OCT (Electron Microscopy Sciences, Hatfield, PA, USA) and immediately frozen in isopentane at $-80^{\circ} \mathrm{C}$ (SigmaAldrich). The sections were stored at $-80^{\circ} \mathrm{C}$ until further processing. For immunohistochemical staining, frozen sections (8 $\mu \mathrm{m}$ thick) were mounted onto SuperFrost Plus glass slides (Fisher Scientific, Pittsburgh, PA, USA) and air-dried overnight. The sections were then fixed with freshly prepared cold $4 \%$ paraformaldehyde and $0.2 \%$ picric acid in PBS for $20 \mathrm{~min}$ at $4{ }^{\circ} \mathrm{C}$. To complete fixation, cryosections were air-dried at room temperature. Tissue sections were rinsed with PBS for 3 min and the sections were incubated with permeabilization solution (1\% Triton $\mathrm{X}-100$ in PBS) for $30 \mathrm{~min}$ at room temperature. The sections were blocked in $0.5 \%$ donkey serum and $0.1 \%$ Tween-20 for $60 \mathrm{~min}$ at room temperature, after quenching endogenous peroxidase activity by exposing 
slides to 'Peroxidase Block' (Kit LSAB + System-HRP; DAKO, Mississauga, ON, Canada) for $5 \mathrm{~min}$. The sections were then incubated with primary antibodies diluted in blocking solution (Biomeda, Foster City, CA, USA) overnight at $4{ }^{\circ} \mathrm{C}$. The primary antibodies used were goat polyclonal anti-OLR1 antiserum (1:100, Santa Cruz Biotechnology), rabbit polyclonal anti-hCG (1:500, Chemicon), and mouse anti-CD34 (1:1000, NeoMarker, Fremont, CA, USA). To ascertain protein-specific antibody binding, controls (CTL) were performed omitting primary antibodies. Subsequently, they were incubated with endogenous avidin and biotin blocking solutions for $15 \mathrm{~min}$ at room temperature each. Tissue sections were incubated with 'Link' universal secondary antibody solution (DAKO) for $60 \mathrm{~min}$ at room temperature and then with 'streptavidin-peroxidase' for $30 \mathrm{~min}$. They were stained with 'substrate-chromogen solution' (DAKO), and counterstained with Mayer's hematoxylin (Fluka, Buchs, Switzerland). The sections were viewed and photographed under interference contrast Leitz Diaplan microscope equipped with a Nikon CoolPix 990 camera. Cells having intense brownish staining were considered immunopositive.

\section{Cytokine quantification}

Interleukin-1 $\beta$ (IL1B) and TNF concentrations were measured in the total protein fraction extracted from placental tissue, using the Human IL-1 (IL-1b) ELISA Ready-SET-Go! and Human TNF $\alpha$ (TNF) ELISA Ready-SET-Go! Kits (eBioscience, San Diego, CA, USA) according to the manufacturer's instructions.

\section{Statistical analyses}

Data were expressed as the mean \pm S.E.M., and analyzed with unpaired Student's $t$-test at $P<0.05$ level of significance, to evaluated difference between groups. For the relationship between two variables of the same population, the results are expressed as Spearman's correlation and the curve represent Pearson's linear correlation. All statistical analyses were performed using the Prism software (version 4.0.2, 2004; GraphPad Software, La Jolla, CA, USA).

\section{Declaration of interest}

The authors declare that there is no conflict of interest that could be perceived as prejudicing the impartiality of the research reported.

\section{Funding}

This study was supported by grant from Canadian Institutes of Health Research (CIHR: NET 2002-2007).

\section{Acknowledgements}

The authors express their gratitude to the staff of Département d'Obstétrique et de Gynécologie, Pavillon St-Luc (CHUM) for the donation of placentas, to Marie-Claude Charest for the correction of this paper and to Dave Lanoix for its scientific support.

\section{References}

Bonet B, Chait A, Gown AM \& Knopp RH 1995 Metabolism of modified LDL by cultured human placental cells. Atherosclerosis 112 125-136.

Butte NF 2000 Carbohydrate and lipid metabolism in pregnancy: normal compared with gestational diabetes mellitus. American Journal of Clinical Nutrition 71 1256S-1261S.

Cao G, Garcia CK, Wyne KL, Schultz RA, Parker KL \& Hobbs HH 1997 Structure and localization of the human gene encoding SR-BI/CLA-1. Evidence for transcriptional control by steroidogenic factor 1. Journal of Biological Chemistry 272 33068-33076.

Challier JC, Hauguel S \& Desmaizieres V 1986 Effect of insulin on glucose uptake and metabolism in the human placenta. Journal of Clinical Endocrinology and Metabolism 62 803-807.

Chen H 2006 Cellular inflammatory responses: novel insights for obesity and insulin resistance. Pharmacological Research 53 469-477.

Chen H, Li D, Sawamura T, Inoue K \& Mehta JL 2000a Upregulation of LOX-1 expression in aorta of hypercholesterolemic rabbits: modulation by losartan. Biochemical and Biophysical Research Communications 276 1100-1104.

Chen M, Kakutani M, Minami M, Kataoka H, Kume N, Narumiya S, Kita T, Masaki T \& Sawamura T 2000b Increased expression of lectin-like oxidized low density lipoprotein receptor-1 in initial atherosclerotic lesions of Watanabe heritable hyperlipidemic rabbits. Arteriosclerosis, Thrombosis, and Vascular Biology 20 1107-1115.

Chen M, Nagase M, Fujita T, Narumiya S, Masaki T \& Sawamura T 2001 Diabetes enhances lectin-like oxidized LDL receptor-1 (LOX-1) expression in the vascular endothelium: possible role of LOX-1 ligand and AGE. Biochemical and Biophysical Research Communications 287 962-968.

Chen J, Li D, Schaefer R \& Mehta JL 2006 Cross-talk between dyslipidemia and renin-angiotensin system and the role of LOX-1 and MAPK in atherogenesis studies with the combined use of rosuvastatin and candesartan. Atherosclerosis 184 295-301.

Chiba Y, Ogita T, Ando K \& Fujita T 2001 PPARgamma ligands inhibit TNF$\alpha$-induced LOX-1 expression in cultured endothelial cells. Biochemical and Biophysical Research Communications 286 541-546.

Di Cianni G, Miccoli R, Volpe L, Lencioni C \& Del Prato S 2003 Intermediate metabolism in normal pregnancy and in gestational diabetes. Diabetes/Metabolism Research and Reviews 19 259-270.

Cominacini L, Pasini AF, Garbin U, Davoli A, Tosetti ML, Campagnola M, Rigoni A, Pastorino AM, Lo Cascio V \& Sawamura T 2000 Oxidized low density lipoprotein (ox-LDL) binding to ox-LDL receptor-1 in endothelial cells induces the activation of NF- $\mathrm{KB}$ through an increased production of intracellular reactive oxygen species. Journal of Biological Chemistry 275 12633-12638.

Cummings SW, Hatley W, Simpson ER \& Ohashi M 1982 The binding of high and low density lipoproteins to human placental membrane fractions. Journal of Clinical Endocrinology and Metabolism $\mathbf{5 4}$ 903-908.

Dejager S, Bruckert E \& Chapman MJ 1993 Dense low density lipoprotein subspecies with diminished oxidative resistance predominate in combined hyperlipidemia. Journal of Lipid Research 34 295-308.

Fialova L, Mikulikova L, Malbohan I, Benesova O, Stipek S, Zima T \& Zwinger A 2002 Antibodies against oxidized low density lipoproteins in pregnant women. Physiological Research 51 355-361.

Forest J, Garrido-Russo M, Lemay A, Carrier R \& Dubé JL 1983 Reference values for the oral glucose tolerance test at each trimester of pregnancy. American Journal of Clinical Pathology 80 828-831.

Forest J, Masse JC \& Garrido-Russo M 1994 Glucose tolerance test during pregnancy: the significance of one abnormal value. Clinical Biochemistry 24 299-304.

Gafvels ME, Coukos G, Sayegh R, Coutifaris C, Strickland DK \& Strauss JF III 1992 Regulated expression of the trophoblast alpha 2-macroglobulin receptor/low density lipoprotein receptor-related protein. Differentiation and CAMP modulate protein and mRNA levels. Journal of Biological Chemistry 267 21230-21234.

Gitto E, Reiter RJ, Karbownik M, Tan DX, Gitto P, Barberi S \& Barberi I 2002 Causes of oxidative stress in the pre- and perinatal period. Biology of the Neonate 81 146-157. 
Gratacos E, Casals E, Deulofeu R, Cararach V, Alonso PL \& Fortuny A 1998 Lipid peroxide and vitamin $E$ patterns in pregnant women with different types of hypertension in pregnancy. American Journal of Obstetrics and Gynecology 178 1072-1076.

Greenberg AS \& Obin MS 2006 Obesity and the role of adipose tissue in inflammation and metabolism. American Journal of Clinical Nutrition $\mathbf{8 3}$ 461S-465S.

Grundy SM 2004 Obesity, metabolic syndrome, and cardiovascular disease. Journal of Clinical Endocrinology and Metabolism 89 2595-2600.

Gwynne JT \& Mahaffee DD 1989 Rat adrenal uptake and metabolism of high density lipoprotein cholesteryl ester. Journal of Biological Chemistry 264 8141-8150.

Halvorsen B, Staff AC, Henriksen T, Sawamura T \& Ranheim T 2001 8-isoprostaglandin $F(2 \alpha)$ increases expression of LOX-1 in JAR cells. Hypertension 37 1184-1190.

Havel PJ 2004 Update on adipocyte hormones: regulation of energy balance and carbohydrate/lipid metabolism. Diabetes 53 (Supplement 1) S143-S151.

Heitritter SM, Solomon CG, Mitchell GF, Skali-Ounis N \& Seely EW 2005 Subclinical inflammation and vascular dysfunction in women with previous gestational diabetes mellitus. Journal of Clinical Endocrinology and Metabolism 90 3983-3988.

Herrera E 2002 Lipid metabolism in pregnancy and its consequences in the fetus and newborn. Endocrine 19 43-55

Hofnagel O, Luechtenborg B, Eschert H, Weissen-Plenz G, Severs NJ \& Robenek H 2006 Pravastatin inhibits expression of lectin-like oxidized low-density lipoprotein receptor-1 (LOX-1) in Watanabe heritable hyperlipidemic rabbits: a new pleiotropic effect of statins. Arteriosclerosis, Thrombosis, and Vascular Biology 26 604-610.

Honing ML, Morrison PJ, Banga JD, Stroes ES \& Rabelink TJ 1998 Nitric oxide availability in diabetes mellitus. Diabetes/Metabolism Reviews 14 241-249.

Kaaja R 1998 Insulin resistance syndrome in preeclampsia. Seminars in Reproductive Endocrinology 16 41-46.

Kanne JP, Lalani TA \& Fligner CL 2005 The placenta revisited: radiologicpathologic correlation. Current Problems in Diagnostic Radiology 34 238-255.

Kataoka H, Kume N, Miyamoto S, Minami M, Murase T, Sawamura T, Masaki T, Hashimoto N \& Kita T 2000 Biosynthesis and post-translational processing of lectin-like oxidized low density lipoprotein receptor-1 (LOX-1). N-linked glycosylation affects cell-surface expression and ligand binding. Journal of Biological Chemistry 275 6573-6579.

King JC 2006 Maternal obesity, metabolism, and pregnancy outcomes. Annual Review of Nutrition 26 271-291.

Kita T, Kume N, Minami M, Hayashida K, Murayama T, Sano H, Moriwaki H, Kataoka $H$, Nishi E, Horiuchi $H$, Arai $H$ \& Yokode $M$ 2001 Role of oxidized LDL in atherosclerosis. Annals of the New York Academy of Sciences 947 199-205 (discussion 205-196).

Koukkou E, Watts GF \& Lowy C 1996 Serum lipid, lipoprotein and apolipoprotein changes in gestational diabetes mellitus: a crosssectional and prospective study. Journal of Clinical Pathology 49 634-637.

Kume N, Murase T, Moriwaki H, Aoyama T, Sawamura T, Masaki T \& Kita T 1998 Inducible expression of lectin-like oxidized LDL receptor-1 in vascular endothelial cells. Circulation Research 83 322-327.

Kume N, Moriwaki H, Kataoka H, Minami M, Murase T, Sawamura T, Masaki T \& Kita T 2000 Inducible expression of LOX-1, a novel receptor for oxidized LDL, in macrophages and vascular smooth muscle cells Annals of the New York Academy of Sciences 902 323-327.

Lafond J, Auger D, Fortier J \& Brunette MG 1988 Parathyroid hormone receptor in human placental syncytiotrophoblast brush border and basal plasma membranes. Endocrinology 123 2834-2840.

Lafond J, Charest MC, Alain JF, Brissette L, Masse A, Robidoux J \& Simoneau L 1999 Presence of CLA-1 and HDL binding sites on syncytiotrophoblast brush border and basal plasma membranes of human placenta. Placenta 20 583-590.

Lee H, Park H, Kim YJ, Kim HJ, Ahn YM, Park B, Park JH \& Lee BE 2005 Expression of lectin-like oxidized low-density lipoprotein receptor-1 (LOX-1) in human preeclamptic placenta: possible implications in the process of trophoblast apoptosis. Placenta 26 226-233.
Li D \& Mehta JL 2000 Antisense to LOX-1 inhibits oxidized LDL-mediated upregulation of monocyte chemoattractant protein-1 and monocyte adhesion to human coronary artery endothelial cells. Circulation 101 2889-2895.

Li L, Sawamura T \& Renier G 2003 Glucose enhances endothelial LOX-1 expression: role for LOX-1 in glucose-induced human monocyte adhesion to endothelium. Diabetes 52 1843-1850.

Li L, Sawamura T \& Renier G 2004 Glucose enhances human macrophage LOX-1 expression: role for LOX-1 in glucose-induced macrophage foam cell formation. Circulation Research 94 892-901.

Mehta JL, Chen J, Hermonat PL, Romeo F \& Novelli G 2006 Lectin-like, oxidized low-density lipoprotein receptor-1 (LOX-1): a critical player in the development of atherosclerosis and related disorders. Cardiovascular Research 69 36-45.

Moriwaki H, Kume N, Sawamura T, Aoyama T, Hoshikawa H, Ochi H, Nishi E, Masaki T \& Kita T 1998 Ligand specificity of LOX-1, a novel endothelial receptor for oxidized low density lipoprotein. Arteriosclerosis, Thrombosis, and Vascular Biology 18 1541-1547.

Nagase M, Hirose S, Sawamura T, Masaki T \& Fujita T 1997 Enhanced expression of endothelial oxidized low-density lipoprotein receptor (LOX-1) in hypertensive rats. Biochemical and Biophysical Research Communications 237 496-498.

Pavan L, Hermouet A, Tsatsaris V, Therond P, Sawamura T, Evain-Brion D \& Fournier T 2004 Lipids from oxidized low-density lipoprotein modulate human trophoblast invasion: involvement of nuclear liver $\mathrm{X}$ receptors. Endocrinology 145 4583-4591.

Rajman I, Eacho PI, Chowienczyk PJ \& Ritter JM 1999 LDL particle size: an important drug target? British Journal of Clinical Pharmacology 48 125-133.

Ramsay JE, Ferrell WR, Crawford L, Wallace AM, Greer IA \& Sattar N 2002 Maternal obesity is associated with dysregulation of metabolic, vascular, and inflammatory pathways. Journal of Clinical Endocrinology and Metabolism 87 4231-4237.

Robidoux J, Simoneau L, St-Pierre S, Ech-Chadli H \& Lafond J 1998 Human syncytiotrophoblast NPY receptors are located on BBM and activate PLCto-PKC axis. American Journal of Physiology 274 E502-E509.

Rosen P, Nawroth PP, King G, Moller W, Tritschler HJ \& Packer L 2001 The role of oxidative stress in the onset and progression of diabetes and its complications: a summary of a Congress Series sponsored by UNESCOMCBN, the American Diabetes Association and the German Diabetes Society. Diabetes/Metabolism Research and Reviews 17 189-212.

Ross R 1999 Atherosclerosis - an inflammatory disease. New England Journal of Medicine 340 115-126.

Sacks GP, Studena K, Sargent K \& Redman CW 1998 Normal pregnancy and preeclampsia both produce inflammatory changes in peripheral blood leukocytes akin to those of sepsis. American Journal of Obstetrics and Gynecology 179 80-86.

Sakurai K \& Sawamura T 2003 Stress and vascular responses: endothelial dysfunction via lectin-like oxidized low-density lipoprotein receptor-1: close relationships with oxidative stress. Journal of Pharmacological Sciences 91 182-186.

Sanchez-Vera I, Bonet B, Viana M, Quintanar A, Martin MD, Blanco P, Donnay S \& Albi M 2007 Changes in plasma lipids and increased lowdensity lipoprotein susceptibility to oxidation in pregnancies complicated by gestational diabetes: consequences of obesity. Metabolism $\mathbf{5 6}$ $1527-1533$.

Sawamura T, Kume N, Aoyama T, Moriwaki H, Hoshikawa H, Aiba $Y$, Tanaka T, Miwa S, Katsura Y, Kita T \& Masaki T 1997 An endothelial receptor for oxidized low-density lipoprotein. Nature 386 73-77.

Serdar Z, Gur E, Develioglu O, Colakogullari M \& Dirican M 2002 Placental and decidual lipid peroxidation and antioxidant defenses in preeclampsia. Lipid peroxidation in preeclampsia. Pathophysiology 921

Spranger J, Kroke A, Mohlig M, Hoffmann K, Bergmann MM, Ristow M, Boeing H \& Pfeiffer AF 2003 Inflammatory cytokines and the risk to develop type 2 diabetes: results of the prospective population-based European Prospective Investigation into Cancer and Nutrition (EPIC)Potsdam Study. Diabetes 52 812-817.

Steinberg D 1997 Lewis A. Conner Memorial Lecture. Oxidative modification of LDL and atherogenesis. Circulation 95 1062-1071. 
Stevens MJ 2005 Oxidative-nitrosative stress as a contributing factor to cardiovascular disease in subjects with diabetes. Current Vascular Pharmacology 3 253-266.

Tames FJ, Mackness MI, Arrol S, Laing I \& Durrington PN 1992 Nonenzymatic glycation of apolipoprotein $\mathrm{B}$ in the sera of diabetic and nondiabetic subjects. Atherosclerosis 93 237-244.

Taskinen MR 1990 Hyperlipidaemia in diabetes. Baillière's Clinical Endocrinology and Metabolism 4 743-775.

Toescu V, Nuttall SL, Martin U, Kendall MJ \& Dunne F 2002 Oxidative stress and normal pregnancy. Clinical Endocrinology 57 609-613.

Walsh SW \& Wang Y 1993 Secretion of lipid peroxides by the human placenta. American Journal of Obstetrics and Gynecology 169 1462-1466.

Warth MR, Arky RA \& Knopp RH 1975 Lipid metabolism in pregnancy. II. Altered lipid composition in intermediage, very low, low and highdensity lipoprotein fractions. Journal of Clinical Endocrinology and Metabolism 41 649-655.

Wisdom SJ, Wilson R, McKillop JH \& Walker JJ 1991 Antioxidant systems in normal pregnancy and in pregnancy-induced hypertension. American Journal of Obstetrics and Gynecology 165 1701-1704.

Wittmaack FM, Gafvels ME, Bronner $M$, Matsuo $H$, McCrae KR, Tomaszewski JE, Robinson SL, Strickland DK \& Strauss JF III 1995
Localization and regulation of the human very low density lipoprotein/ apolipoprotein-E receptor: trophoblast expression predicts a role for the receptor in placental lipid transport. Endocrinology 136 340-348.

Witztum JL \& Horkko S 1997 The role of oxidized LDL in atherogenesis: immunological response and anti-phospholipid antibodies. Annals of the New York Academy of Sciences 811 88-96 (discussion 96-89).

Xiang AH, Peters RK, Trigo E, Kjos SL, Lee WP \& Buchanan TA 1999 Multiple metabolic defects during late pregnancy in women at high risk for type 2 diabetes. Diabetes 48 848-854.

Yoshida H, Kondratenko N, Green S, Steinberg D \& Quehenberger O 1998 Identification of the lectin-like receptor for oxidized low-density lipoprotein in human macrophages and its potential role as a scavenger receptor. Biochemical Journal 334 9-13.

Received 21 February 2008

First decision 7 May 2008

Accepted 2 July 2008 